\section{Relationship between educational stress and psychological resilience in nursing students}

\author{
Bedia Tarsuslu ${ }^{1}$ \\ Nevin Günaydın ${ }^{2}$ \\ Medine Koç ${ }^{3}$
}

\section{Öğrenci hemşirelerde eğitim stresi ile psikolojik dayanıklılık arasındaki ilişki}

\begin{abstract}
Aim: The aim of this study was to determine the relationship between educational stress and psychological resilience in nursing students.

Method: The descriptive and analytical design of the study consists of 602 students in the nursing department of the Faculty of Health Sciences of Ordu and Tokat Gaziosmanpasa University. Data were collected using Personal Information Form, Nursing Education Stress Scale (NESS), and Resilience Scale for Adults (RSA). Data, frequency distribution, descriptive statistics (mean, standard deviation) Mann Whitney U test, Kruskal Wallis test, and Spearman correlation test were used.

Findings: The mean age of the students was $20.37 \pm 2.10,73.8 \%$ of them were women, the mean NESS score was $66.76 \pm 16.56$, and the mean RSA score was 99.99 \pm 5.19 . There was a high positive correlation between NESS total, academic and application sub-dimensions, RSA structural style and future perception, NESS total and academic sub-dimension was negatively correlated with social resources and NESS academic and family cohesion.
\end{abstract}

Özet

Amaç: $\mathrm{Bu}$ çalışmanın amacı, hemşirelik öğrencilerinin eğitim stresi ile psikolojik dayanıklılıkları arasındaki ilişkiyi ve etkileyen faktörleri belirlemektir.

Metod: Tanımlayıcı ve analitik tipte planlanan araştırmaya, Ordu ve Tokat Gaziosmanpaşa Üniversitesi Sağlık Bilimleri Fakültesi Hemşirelik Bölümünde öğrenim gören 602 öğrenci dahil edilmiştir. Veriler, Kişisel Bilgi Formu, Hemşirelik Eğitimi Stres Ölçeği (HESÖ) ve Yetişkinler için Psikolojik Dayanıklılık Ölçeği (YPDÖ) kullanilarak topland. Verilerin analizinde, frekans dağılımı ve tanımlayıcı istatistikler (ortalama, standart sapma), Mann Whitney U, Kruskal Wallis ve Spearman korelasyon testi kullanild.

Bulgular: Öğrencilerin yaş ortalaması $20.37 \pm 2.10, \quad \% 73.8$ ' kadın, HESÖ puan ortalamas1 $66,76 \pm 16,56$, YPDÖ puan ortalamas

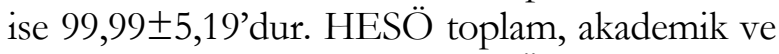
uygulama alt boyutları ile YPDÖ yapisal stil ve gelecek algisı arasında yüksek derecede pozitif yönde, HESÖ toplam ve akademik alt boyutu ile sosyal kaynaklar arasında ve HESÖ akademik ile

\footnotetext{
${ }^{1}$ Res. Assist.., Department of Psychiatric Nursing, Faculty of Health Science, Sakarya University, Sakarya, Turkey. tarsuslubedia@gmail.com

2 Assist. Prof. Dr., Department of Psychiatric Nursing, Faculty of Health Science, Ordu University, Ordu, Turkey. gunaydinnevin@gmail.com

${ }^{3}$ Assist. Prof. Dr., Department of Psychiatric Nursing, Faculty of Health Science, Tokat Gaziosmanpasa University, Tokat, Turkey. medine.koc@gop.edu.tr
} 
Tarsuslu, B., Günaydın, N., \& Koc, M. (2020). Öğrenci hemșirelerde eğitim stresi ile psikolojik dayanıklılı arasındaki ilişki. Journal of Human Sciences, 17(1), 79-91. doi:10.14687/jhs.v17i1.5796

Conclusions: Acording to results, nursing students experience moderate academic and practice stress. Among the factors that affect students' psychological well-being, there is a positive relationship between personal strength and future goals, quests and adaptation to future, and stress (in practice area). In addition, it can be said that the psychological resilience of the students is moderate when the scores of the students are evaluated.

Keywords: Nursing; nursing education; student; educational stress; resilience.

(Extended English summary is at the end of this document) aile uyumu arasında negatif yönde ilişki olduğu saptandi.

Sonuç: Hemşirelik öğrencileri orta düzeyde akademik ve uygulama alanlarında stres deneyimlemektedir. Öğrencilerin psikolojik iyi oluşlarını etkileyen faktörlerden kişisel özellikler ve geleceğe yönelik yeni amaç, arayışlar ve geleceğe uyumları ile stres (uygulama alanında) arasında pozitif ilişki bulunmaktadır. Ayrıca, öğrencilerin YPDÖ puanlanına bakıldığında, psikolojik dayanıklılıklarının orta derece olduğu söylenebilir.

Anahtar Kelimeler: Hemşirelik; hemşirelik eğitimi, öğrenci; eğitim stresi; dayanıklılık.

\section{Giriş}

Hemşirelik eğitimi teorik bilgi, gözlem, yorum ve el becerilerinin kazanılmasını hedefleyen, teorik ve uygulamayı kapsayan dinamik bir süreçtir (Karaca, Yildirim, Ankarali ve Açikgöz, 2014). $\mathrm{Bu}$ eğitim süresince, öğrencilerden hasta-sağlıklı birey, aile, toplumun sağlığını geliştirmeye yönelik ve sağlık problemlerine çözüm getiren bilimsel yöntemlere dayalı bilgi, tutum ve becerileri kazanmaları amaçlanmaktadır (Kang, Choi ve Ryu, 2009). Öğrenciler bu becerileri kazanmaya çalışırken, olumlu deneyimlerin yanında travmatik veya stres verici deneyimler de yaşayabilmektedir (Mooney, 2007).

Stres, hemşirelik öğrencilerinin eğitimleri süresince deneyimledikleri evrensel bir problemdir. Sağlık alanındaki diğer disiplinlerde eğitim alan öğrencilerle kıyaslandığında, hemşirelik öğrencilerinde ruh sağlığına ilişkin problemlerinin gelişme riskinin daha yüksek olduğu bildirilmektedir (Edwards, Burnard, Bennett ve Hebden, 2010). Stresin bireyler üzerinde baz1 olumlu etkileri olduğu bilinse de, hemşirelik öğrencileri üzerinde bilişsel, duygusal, fizyolojik veya davranışsal birçok olumsuz etkileri olduğunu gösteren kanıtlar bulunmaktadır. Stresin olumsuz bilişsel etkileri arasında; etkisiz başa çıkma, korku, endişe ve bunalmış hissetme (Goff, 2009; Chernomas ve Shapiro, 2013), duygusal etki olarak; sinirlilik, halsizlik, moral bozukluğu, kendine güvende azalma, konsantrasyon düşüklüğü, odaklanma ve motivasyon kayb1 (Goff, 2009; Chernomas ve Shapiro, 2013) görülmektedir. Fizyolojik olarak ise; çarpınt, bulant, kusma (Jimenez ve ark., 2010; Chernomas ve Shapiro, 2013;), ağlama, sinirlilik, bitkinlik (Goff, 2009), baş dönmesi, terleme (Jimenez ve ark., 2010) gibi durumlar ortaya çıkmaktadır. Hemşirelik öğrencileri, akademik performanslarını ve yaşam kalitelerini etkileyen pek çok stresörle karşılaşmaktadır (Sheu, Lin ve Hwang, 2002; Pulido-Martos, Augusto-Landa ve Lopez-Zafra, 2012). Bu stresörler arasinda akademik stresin yanında klinik ortam öğrenciler için temel stres kaynağ1 olarak belirtilmektedir (Gibbons, Dempster ve Moutray, 2011; Chernomas \& Shapiro, 2013; Chen \& Hung, 2014; Wolf, Warner Stidham, Ross ve Warner, 2015).

Stres ve kayg1, hemşirelik öğrencilerinde akademik ve klinik performansın yanında sağlığı ve iyilik halini etkilemektedir (Jimenez ve ark., 2010; Gibbons ve ark., 2011; Klainin-Yobas ve ark., 2014). Yaşanan stresin artması durumunda, öğrencilerin düşünme ve karar verme yeterlilikleri olumsuz etkilenerek, akademik başarllarının düştüğü (Maville, Kranz ve Tucker, 2004), mental sorunlar yanında kalp hastalığı, hipertansiyon, immün yetmezlik gibi sağlık sorunlarının da ortaya çıktığ1 görülebilmektedir (Lee, Holzemer ve Faucett, 2007). Stresin neden olduğu bu olumsuz etkiler ile bireyin etkili baş etme davranışları arasında ilişki bulunmaktadır (Schabracq, Winnubst ve Cooper, 2004; Edwards ve ark., 2010). Etkili başa çıkma stratejilerini kullanabilme, bireylerin hem 
Tarsuslu, B., Günaydın, N., \& Koc, M. (2020). Öğrenci hemșirelerde eğitim stresi ile psikolojik dayanıklılı arasındaki ilişki. Journal of Human Sciences, 17(1), 79-91. doi:10.14687/jhs.v17i1.5796

ruhsal hem fiziksel sağlıkları üzerinde koruyucu bir faktördür (Schabracq ve ark., 2004; Chan, So ve Fong, 2009).

Öğrencilerin deneyimledikleri stresli olay/durum karşısında kaygı, öfke, depresyon gibi bazı ruhsal problemlerde, kendilerini çabuk toparlayabilmelerini sağlayan en önemli faktörlerden biri psikolojik dayanıklılık düzeyidir. Psikolojik dayanıklılık, travma, kişilerarası sıkıntılar, sağlık problemleri gibi stres yaratan kaynaklar karşısında uyum sağlama süreci (Tusaie \& Dyer, 2004), kendini toparlama gücü (Garmezy, 1991) veya bu durumların üstesinden başarllı bir şekilde gelebilme yeteneği (Wagnild \& Young, 1993) olarak tanımlanmaktadır. Psikolojik olarak dayanıklılık düzeyi yüksek bireyler, yaşadıkları stres verici durumlarla daha etkili baş edebilmekte ve ilerideki stresli durumlarda daha güçlü olabilmektedir (Özer, 1994).

Üniversitelerde eğitim alan hemşirelik öğrencilerinin, eğitim hayatı boyunca yaşadıkları stres kaynaklarının ve psikolojik dayanıklılık düzeylerinin bilinmesi, anlaşılması ve aralarındaki ilişkinin ortaya konması, öğrencilerin profesyonel bir mesleki kimlik kazanmalarında etkili bir faktördür. Eğitimleri süresince hem sosyal sorunlarıla, hem de kriz yaşayan sağllklı/hasta birey, aile ve topluma hizmet veren hemşire adaylarının her açıdan donanımlı bir şekilde mezun olmaları hedeflenmektedir. Hemşirelik öğrencilerinin, mesleki değişim, gelişim ve profesyonel bilgi, tutum, beceri kazanarak mezun olmaları için öğrencilerin deneyimledikleri akademik ve teorik eğitim stresi ile psikolojik dayanıklılıkları arasındaki ilişkiyi ortaya koymak önemlidir. Bu doğrultuda bu çalışmada, hemşirelik öğrencilerinin deneyimledikleri eğitim stresi ile psikolojik açıdan dayanıklılıkları arasındaki ilişkiyi ve etkileyen bireysel faktörleri belirlemek amaçlanmıştır.

\section{Gereç ve Yöntem}

\section{Örneklem}

Tanımlayıcı ve analitik tipte planlanan araştırmanın evrenini Ordu Üniversitesi’nden 420 ve Tokat Gaziosmanpaşa Üniversitesi Sağlık Bilimleri Fakültesi’nden 450 Hemşirelik Bölümü öğrencisi oluşturmaktadır. Örneklem büyüklüğü; "Evren Büyüklüğü Bilinen Örneklem Hesaplama Formülü"ne göre 267 olarak belirlenmiştir. Çalışma konusunun bireysel özellikler boyutu göz önünde tutularak örneklem sayısının iki katına $(n=552)$ ulaşılmaya çalışılmıştır. Tabakalı örnekleme yöntemine göre de Ordu Üniversitesi'nden en az 129, Tokat Gaziosmanpaşa Üniversitesi Sağlık Bilimleri Fakültesi'nden en az 138 hemşirelik bölümü öğrencisi alınması hedeflenmiştir. Araştırmaya katılmayı gönüllü olarak kabul eden öğrencilere "anket formu" sınıf ortamında dağıtılmış ve 602 öğrencinin katılımı ile gerçekleştirilmiştir.

\section{Veri Toplama Araçları}

Veriler öğrencilerin sosyo-demografik bilgilerini sorgulayan "Kişisel Bilgi Formu", hemşirelik eğitimine bağlı stres düzeylerini ölçmek için "Hemşirelik Eğitimi Stres Ölçeği”, bireyin yaşamında bir başanıy veya uyum sağlama sürecini tanımlayan psikolojik dayanıklılıklarını değerlendirmek için "Yetişkinler için Psikolojik Dayanıklılık Ölçeğì" kullanılarak toplandı.

Kişisel Bilgi Formu: Bu form öğrencilerin cinsiyet, yas, sınıf, medeni durum, kaldığ1 yer vb. olmak üzere 8 sorudan oluşmaktadır.

Hemşirelik Eğitimi Stres Ölçeği (HESÖ): Hemşirelik Eğitimi Stres Ölçeği, hemşirelik öğrencilerinin eğitim hayatı boyunca deneyimledikleri stresi değerlendirmek amacı ile kullanılmaktadır. Ölçek, Rhead (1995) tarafindan, Gray-Toft ve Anderson'un geliştirdiği Hemşire Stres Ölçeğinin modifiye edilmesiyle oluşturulmuştur. HESÖ, 32 maddeden ve iki alt boyuttan (uygulama stresi ve akademik stres) oluşan, dörtlü (0-3 puan) Likert tipinde bir ölçüm aracıdır. Ölçüm aracının her bir alt boyutu, 0 ile 48 arasında değer almakta, toplam puanı 0 ile 96 arasındadır ve puanın artması stres düzeyinin arttı̆̆1 anlamına gelmektedir. Ölçüm aracının Türkçe'ye uyarlanması, Karaca ve ark. (2014) tarafindan gerçekleştirilmiştir.

Yetişkinler için Psikolojik Dayanıklılık Ölçeği (YPDÖ): YPDÖ, Friborg ve ark. (2003) tarafindan geliştirilmiştir; "kissisel güç", "yapısal stil", "sosyal yeterlilik", "aile uyumu" ve "sosyal kaynaklar” boyutlarını içermektedir. Daha sonra Friborg ve ark.nın (2005) yaptkkları çalışma, ölçeğin 
Tarsuslu, B., Günaydın, N., \& Koc, M. (2020). Öğrenci hemșirelerde eğitim stresi ile psikolojik dayanıklılık arasındaki ilişki. Journal of Human Sciences, 17(1), 79-91. doi:10.14687/jhs.v17i1.5796

altı boyutlu yapısının psikolojik dayanıklılık modelini daha iyi açılkladığını göstermiştir. Bu çalışmada, "kişisel güç" boyutu "kendilik algısı" ve "gelecek algısı" biçiminde ikiye ayrılmış ve YPDÖ, toplam altı boyutlu bir yapı olmuştur. YPDÖ, 33 sorudan oluşmaktadır. Ölçekte, "yapısal stil" ve "gelecek alg1s1" 4'er madde; "aile uyumu", "kendilik algisı", "sosyal yeterlilik" 6'şar madde ve "sosyal kaynaklar" ise 7 maddeden oluşmaktadır. YPDÖ'den alınan puanların artması, psikolojik dayanıklılık düzeyinin yüksek olduğunu göstermektedir. YPDÖ’nün Türkçe’ye uyarlanması, Basım ve Çetin (2011) tarafindan gerçekleştirilmiştir.

\section{İstatistiksel değerlendirme}

Veriler, bilgisayar ortamında veri analiz programına aktarılarak değerlendirildi. Araştırma verileri değerlendirilirken kategorik değişkenler için frekans dağılımı, sayısal değişkenler için tanımlayıcı istatistikler (ortalama $\_$standart sapma) kullanıldı. Sürekli verilerin normal dağılıma uyup uymadığ1 Kolmogorov-Smirnov testiyle sınandı ve veriler normal dağılıma uymadığı için ikili grupların karşılaştırılmasında Mann Whitney $U$ testi, üç ve daha fazla grubun karşılaştırılmasında ise Kruskal Wallis testi, değişkenlerin birbiri ile ilişkilerini belirlemede Spearman korelasyon testi kullanıldı. Ayrıca ölçek güvenilirlikleri için cronbach alfa değerlerinden yararlanıldı. İstatistiksel açıdan anlamlılık için $\mathrm{p}<0.05$ kabul edildi.

\section{Etik İlkeler}

Araştırma, Ordu Üniversitesi 2018-32 sayılı ve 01.03.2018 tarihli etik kurul onayı ve iki üniversiteden de araştırmanın yapılabilmesi için izin alındıktan sonra, Mart-Nisan 2018 tarihlerinde, öğrencilerin sözlü ve yazılı gönüllü onamları alınarak gerçekleştirildi. Veri toplama sürecinde, Helsinki Bildirgesinde belirtilen kurallara uygun hareket edildi.

\section{Bulgular}

Araşturmaya katılan öğrencilerin bireysel özellikleri incelendiğinde, yaş ortalaması

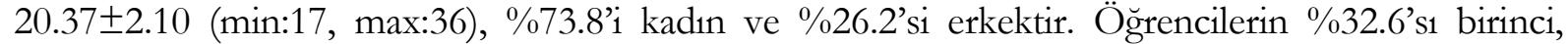
\%26.9'u ikinci, \%24.1'i üçüncü ve \%16.4'ü dördüncü sınıftır. \%67.6's1 yurtta, \%18.6's1 aile yanında, \%13.8'i evde kalmakta ve \%5.8'i ekonomik durumunu düşük, \%69.3'ü orta, \%24.9’u iyi olarak değerlendirmektedir. Ayrıca, \%27.7'sinin duygusal anlamda bir ilisskisi vardır, \%8.5'inin bir kronik hastalığ1 ve \%4.5’inin bir ruhsal rahatsızlığı bulunmaktadır (Tablo 1).

Öğrencilerin ölçeklerden aldıkları puan ortalamalarına bakıldığı zaman, HESÖ toplam puan

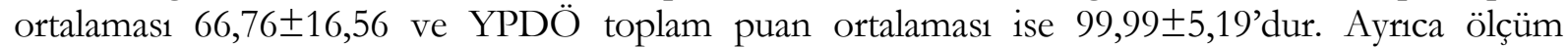
araçlarının cronbach alpha ve ölçeklerin alt boyutlarından aldıkları puan ortalamaları Tablo 2'de verildi.

Öğrencilerin sosyo demografik özelliklerine göre ölçek puan ortancaları karşılaştırıldığında, kız öğrencilerin erkek öğrencilere ve yurtta kalan öğrencilerin ailesinin yanında kalanlara göre HESÖ ve alt puan ortancalarının istatistiksel olarak daha yüksek olduğu görüldü ( $<<0,05)$ (Tablo 3).

Kadın öğrencilerin, erkek öğrencilere göre YPDÖ yapısal stil, gelecek ve kendilik algısı puan ortancaları bakımından daha yüksek bulundu. Duygusal ilişkisi olan öğrencilerin olmayanlara göre yapısal stil ve gelecek alg1sı puan ortancalarının daha yüksek olduğu görüldü. Birinci sinıf öğrencilerinin, 4. Sınıf öğrencilerine göre yapısal stil puan ortancaları daha düşük bulundu. Öte yandan, öğrencilerin kronik fiziksel ve ruhsal hastalık durumuna göre HESÖ ve YPDÖ puan ortancalarının farklılaşmadığı saptandı (Tablo 3).

Öğrencilerin yaşları ile HESÖ ve YPDÖ puanları arasında istatistiksel olarak anlamlı ilişki görülmedi (Tablo 4). HESÖ ile YPDÖ puan ortalamaları arasındaki korelasyon sonuçları Tablo 5'te verildi. HESÖ toplam, akademik ve uygulama alt boyutlanı ile YPDÖ yapisal stil ve/veya gelecek alg1si arasında yüksek derecede pozitif ilişki görüldü. HESÖ toplam ve akademik alt boyutu ile sosyal kaynaklar arasında ve HESÖ akademik ile aile uyumu arasında negatif yönde zayıf bir ilişki olduğu saptandı. 
Tarsuslu, B., Günaydın, N., \& Koc, M. (2020). Öğrenci hemșirelerde eğitim stresi ile psikolojik dayanıklılı arasındaki ilişki. Journal of Human Sciences, 17(1), 79-91. doi:10.14687/jhs.v17i1.5796

\section{Tartışma}

Hemşirelik öğrencileri, belirgin biçimde öğrenmeyi güçleştiren, zorlaştıran stres ve anksiyete deneyimlemektedir (Turner ve McCarthy, 2017). Literatüre bakıldığında öğrenciler için sadece akademik alanın değil, klinik uygulama ortamının da büyük stres kaynağı olduğu görülmektedir (Gibbons ve ark., 2011; Jimenez ve ark., 2010). Araştırmamızda öğrencilerin HESÖ toplam puan ortalaması $(66,76 \pm 16,56)$ olup, HESÖ kullanılarak gerçekleştirilen çalışmalara göre yüksek bulunmuştur (Ergin, Çevik ve Pakiş Çetin, 2018; Çakar, Yıldırım Şişman ve Oruç, 2019; Ozsaban, Turan ve Kaya, 2019). Buna göre araştırmamız örneklemindeki hemşirelik öğrencilerinin, orta düzeyde hemşirelik eğitim stresi deneyimledikleri söylenebilir.

Bireyin stres düzeyi cinsiyet, yaş, ekonomik durum gibi faktörlerden etkilenmektedir. Ergin ve arkadaşlarının (2018) hemşirelik öğrencilerinin eğitimlerine yönelik algıladıkları stres ve başetme biçimlerini incelediği çalışmada, cinsiyete göre akademik stres düzeyleri arasında anlamlı bir farklılık bulunmamıştır. Öte yandan araştırmacılar, uygulama stresi puanının kız öğrencilerde daha yüksek olduğunu saptamışlardır (Ergin ve ark., 2018). Bizim çalışmamızda ise Çakar ve arkadaşlarının (2019) çalışma sonuçları ile benzer biçimde kız öğrencilerin erkeklere göre HESÖ toplam, akademik ve uygulama stres düzeyleri anlamlı derecede yüksek bulunmuştur (Çakar ve ark., 2019).

Bizim çalışmamızda, yurtta kalan öğrencilerin aile yanında kalanlara göre HESÖ toplam ve akademik stres alt boyut puanları anlamlı derecede yüksektir. Birey için aile, sosyal destek sistemlerinin en önemlilerindendir. Aydın ve arkadaşlarının (2017) hemşirelik öğrencileri ile gerçekleştirdiği çalışmada, aile/akraba yanında kalan öğrencilerin yurtta kalanlara göre stresle baş etmede daha fazla iyimser yaklaşım içinde oldukları saptanmıştır (Aydın, Kahraman ve Hiçdurmaz, 2017). Buna göre, öğrencilerin eğitim hayatında deneyimledikleri stresle baş etmede aile desteğinin önemli olduğu söylenebilir.

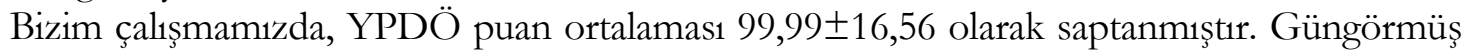
ve ark.nın (2015), hemşirelik öğrencilerinin psikolojik dayanıkllıklarını etkileyen faktörleri incelediği çalışmada, YPDÖ toplam puan ortalaması 125,24 \pm 19,20 ve YPDÖ toplam puan ortalaması ile aileden ya da arkadaștan algılanan sosyal destek ve sosyal destek puan ortalamaları arasinda pozitif güçlü bir korelasyon olduğu saptanmıştır (Güngörmüş, Okanlı ve Kocabeyoğlu, 2015). Bu durum çalışmamızdaki öğrencilerin sosyal desteklerinin Güngörmüş ve arkadaşlarının (2015), çalışmasındaki katlımcılara göre daha düşük seviyede olabileceğini düşündürmektedir. Çalışmamızdaki öğrencilerin puanının daha düşük olması kültürel faktörlerden kaynaklanmış olabilir.

Literatür incelendiğinde psikolojik dayanıklıı̆ın benlik saygısı (Öz \& Yılmaz, 2009; Karairmak \& Çetinkaya Siviş, 2011; McDonald, Jackson, Wilkes ve Vickers, 2012; McCann ve ark., 2013), bilişsel esneklik (Öz ve Hiçdurmaz, 2010; McCann ve ark., 2013; Hart, Brannan ve de Chesnay, 2014; Grant ve Kinman, 2014), iç denetim odağı (Karairmak ve Çetinkaya Siviş, 2011; McDonald ve ark., 2012), Öz yeterlilik (Ablett ve Jones, 2007; Mealer ve ark., 2012; McDonald ve ark., 2012), duyguların farkında olma, duygusal zekâ, duyguları ifade edebilme (Tugade, Fredrickson ve Barrett, 2004; Öz \& Hiçdurmaz, 2010; Armstrong, Galligan ve Critchley, 2011; Grant \& Kinman, 2014;), yenilik arayışında olma, geleceğe yönelik amaç ve olumlu beklentiler, geleceğe uyum sağlama (Öz ve Hiçdurmaz, 2010; Karreman ve Vingerhoets, 2012; McCann ve ark., 2013; Armstrong ve ark., 2011; Grant ve Kinman, 2014; Hart ve ark., 2014) gibi faktörlerle ilişkili olduğu bildirilmektedir. Hemşirelik öğrencileri ile gerçekleştirilen ve psikolojik dayanıklılığı ele alan çalışma sonuçlarına bakıldığında, kız öğrencilerin erkeklere göre; psikolojik dayanıklılık düzeylerinin yüksek olduğu görülmektedir (Güngörmüş ve ark., 2015; Aydın ve ark., 2017; Ozsaban ve ark.; 2019; Çakar ve ark., 2019). Bu sonuçlar, bizim çalışmamızdaki kız öğrencilerin erkeklere göre psikolojik dayanıklılığın bileşenlerinden olan yapısal stil, kendilik algisı ve gelecek algısı puanlarının yüksek olması bulgularını destekler niteliktedir. Bu durum kız öğrencilerin erkeklere göre duygularını ifade etme ve yansıtmada etkin olmaları ile ilişkilendirilebilir (Karaca, Yildirim, Ankarali, Açikgöz ve Akkuş, 2017). 
Tarsuslu, B., Günaydın, N., \& Koc, M. (2020). Öğrenci hemșirelerde eğitim stresi ile psikolojik dayanıklılı arasındaki ilişki. Journal of Human Sciences, 17(1), 79-91. doi:10.14687/jhs.v17i1.5796

Bizim çalışmamızda, 4. sınıf öğrencilerinin 1. sınıflara göre YPDÖ yapısal stil alt boyutu anlamlı derece yüksek bulunmuştur. Ö́zsaban ve arkadaşlarının (2019) hemşirelik öğrencilerinde akademik stres ve sosyal desteğin dayanıklılığa etkisini incelediği çalışmada, ikinci sınıf öğrencilerinin, sosyal kaynak ve aile uyum alt boyut puanlarının diğer sınıflara göre anlamlı derecede yüksek olduğunu bulmuştur (Ozsaban ve ark., 2019). Smith ve Yang (2017) çalışmasında ise, son sınıf öğrencilerinin Genel Sağlık Anketi, stres puanlarının yüksek olduğu ve dayanıklılık düzeylerinin orta seviyede olduğu bildirmektedir (Smith ve Yang, 2017). Öte yandan, Güngörmüş ve arkadaşları (2015) ise öğrencilerin sınıflarına göre psikolojik dayanıklılıklarını incelediğinde 1. ve 4. sınıftaki öğrenciler arasında anlamlı düzeyde bir farklılık olmadığını bildirmiştir (Güngörmüş ve ark., 2015). Bunun aksine Başar ve arkadaşları (2015) hemşirelik öğrencilerinde problem çözme ve iletişim becerilerini değerlendirdiği çalışmasında 4. sınıf öğrencilerin empati düzeylerini 1. sınıflara göre daha yüksek bulmuştur (Başar, Akın ve Durna, 2015). Bu bulgu göz önüne alındığında, öğrencilerin psikolojik dayanıkl1liklarının bireysel psikolojik dayanıklılıklarının empati düzeyleri ve bireysel gelişimleri (Aydın ve ark., 2017) ile ilişkili olabileceğini düşündürmektedir.

Bu çalışmada HESÖ toplam ve klinik uygulama ile YPDÖ yapısal stil ve gelecek algisı arasındaki pozitif ilişki bulunmuştur. Literatürde psikolojik dayanıklılık üzerinde fiziksel güçlülük, iletişim becerisi, zekâ, yetenek, sosyal olma ve öz yeterlilik gibi kişisel özellikler; ebeveyn/ebeveyn yerine geçen birisiyle ilişki içinde olma gibi ailesel özellikler ve arkadaş, öğretmen, komşu gibi sosyal kaynakların rol oynadığı bildirilmektedir (Haase, 2004). Ayrıca geleceğe yönelik yeni amaç, arayışlar içinde olma ve geleceğe uyum psikolojik dayanıklılık üzerinde etkili olmaktadır (Öz \& Hiçdurmaz, 2010; Armstrong ve ark., 2011; Karreman \& Vingerhoets, 2012; McCann ve ark., 2013; Grant ve Kinman, 2014; Hart ve ark., 2014). Hemşirelik öğrencilerinin klinik uygulamalarında karşılaştıkları sağlık risklerini belirlemek amacıyla gerçekleştirilen bir çalısmada, öğrencilerin \%92'sinin klinik uygulamada stres yaşadıkları ve \%61.2'sinde yorgunluk hissettiği bildirilmiştir (Çakar ve ark., 2019). Karaca ve arkadaşları (2017) ise Türk öğrencilerin diğer ülkelerdeki öğrencilere göre daha yüksek düzeyde stres deneyimlediklerini saptamıştır (Karaca ve ark., 2017). Yılmaz ve arkadaşları (2017) hemşirelik öğrencilerinin kendini ifade etme, öfkeyi kontrol etme, kendini yargılama-suçlama ve aşırı duygusal olma gibi bireysel alanda stres yaşadıklarını bildirmektedir (Yılmaz, Yaman ve Erdoğan, 2017). Tüm bu veriler göz önüne alındığında, bu çalışmanın bulgularının literatür ile uyumlu olduğu söylenebilir. Özetle, öğrencilerin eğitim stresi kişisel özellikleri ve gelecek algıları ile ilişkilidir. Eğiticilerin bu durumu eğitim esnasında göz önünde bulundurmaları önerilebilir.

Araştırmamızda HESÖ toplam ve akademik stres ile YPDÖ sosyal kaynak arasında negatif ilişki olduğu görülmüştür. Literatürde, öğrencilerin en çok "Öğretim Elemanları ve Hemşirelerden Kaynaklanan Stres" deneyimledikleri ve hastalarla etkileşimden kaynaklı stres yaşadıkları bildirilmektedir (Ergin ve ark., 2018; Öner Altiok ve Üstün, 2013). Hemşirelerle gerçekleştirilen çalışmalarda, hemşirelerin çalışma arkadaşlarının desteği, stres düzeyini azaltmaktadır (Adriaenssens, Hamelink ve Bogaert, 2017). Öğrenciler ile gerçekleştirilen bir çalş̧mada ise mentör ile çalışan öğrencilerin mentör ile çalışmayanlara göre klinik streslerinin düşük olduğu saptanmıştır (Sü, Özlük ve Demirören, 2018). Öğrencilerin algıladıkları sosyal desteğin artışı ile psikolojik iyi olmanın arttığ1 bildirilmektedir (Aydın ve ark., 2017). Bu sonuçlardan öğrencilerin eğitim ortamındaki sosyal çevreleri arasında onlara rehberlik eden öğretim elemanları ve hemşirelerin büyük rolleri bulunduğu görülmektedir. Eğitim ortamındaki bu sosyal çevrenin destekleyici tutum ve davranış içinde olması öğrencilerin stres düzeyini azaltacaktır. Sosyal destek varlığının psikolojik iyi oluş üzerinde olumlu etkileri olmakta ve stres düzeyini azaltarak ruh sağlığını olumlu yönde etkilemektedir (Armstrong ve ark., 2011; Karreman ve Vingerhoets, 2012).

Bu çalışmada HESÖ akademik stres alt boyutu ile YPDÖ aile uyumu arasında negatif güçlü ilişkinin olduğu bulunmuştur. Literatürde öğrencilerin aile veya arkadaşlarından algıladıkları sosyal destek ve psikolojik dayanıklılıkları arasında pozitif yönde güçlü ilişki olduğuna dair kanıtlar vardır (Güngörmüş ve ark., 2015; Terzi, 2008; Wolf ve ark., 2015). Bu bulgu, aile uyumu yeterli düzeyde olmayan öğrencilerin akademik anlamda daha fazla stres yaşadıklarını ve psikolojik dayanıklılı̆̆ı bir 
Tarsuslu, B., Günaydın, N., \& Koc, M. (2020). Öğrenci hemșirelerde eğitim stresi ile psikolojik dayanıklılı arasındaki ilişki. Journal of Human Sciences, 17(1), 79-91. doi:10.14687/jhs.v17i1.5796

boyutu olan aile uyumu boyutunun yetersiz olduğunu düşündürmektedir. Bu doğrultuda bu boyutla ilişkili olan faktörlerin daha ayrıntılı incelenmesi için yeni araştırmalara gereksinim duyulmaktadır.

\section{Sonuç}

Hemşirelik öğrencileri orta düzeyde akademik ve uygulama alanlarında stres deneyimlemektedir. Kız öğrenciler erkeklere göre, yurtta kalanlar evde kalanlara göre daha fazla stres yaşamaktadırlar. Ayrıca kız öğrenciler, psikolojik dayanıklıllğın alt faktörlerinden olan gelecek alg1s1, yapısal stil ve kendilik alg1sı alanlarında psikolojik olarak daha güçlüdür. Öğrencilerin psikolojik açıdan iyi oluşlarını etkileyen faktörlerden bireysel özellikler ile geleceğe yönelik yeni amaç, arayışlar ve geleceğe uyumları ile stres (uygulama alanında) arasında pozitif ilişki bulunmaktadır. Ayrıca, öğrencilerin YPDÖ puanlarına bakıldığında, psikolojik dayanıklılıklarının orta derece olduğu söylenebilir.

\section{Kaynaklar}

Ablett, J. R. ve Jones, R. S. P. (2007). Resilience and well-being in palliative care staff: a qualitative study of hospice nurses' experience of work. Psycho-Oncology, 16(8), 733-740.

Adriaenssens, J., Hamelink, A. ve Bogaert, P. Van. (2017). Predictors of occupational stress and wellbeing in First-Line Nurse Managers: A cross-sectional survey study. International Journal of Nursing Studies, 73, 85-92.

Armstrong, A. R., Galligan, R. F. ve Critchley, C. R. (2011). Emotional intelligence and psychological resilience to negative life events. Personality and Individual Differences, 51(3), 331-336.

Aydın, A., Kahraman, N. ve Hiçdurmaz, D. (2017). Hemşirelik Öğrencilerinin Alg1lanan Sosyal Destek ve Psikolojik Iyi Olma Düzeylerinin Belirlenmesi. Journal of Psychiatric Nursing, 8(1), 40-47.

Başar, G., Akın, S. ve Durna, Z. (2015). Hemşirelerde ve Hemşirelik Öğrencilerinde Problem Çözme ve İletişim Becerilerinin Değerlendirilmesi. Gümüşhane Üniversitesi Sağllk Bilimleri Dergisi, 4(1), 125-147.

Basım, H. N. ve Çetin, F. (2011). Yetişkinler için Psikolojik Dayanıkllık Ölçeği’nin Güvenilirlik ve Geçerlilik Çalışması. Türk Psikiyatri Dergisi, 22, 1-12.

Çakar, M., Yıldırım Şişman, N. ve Oruç, D. (2019). Hemşirelik Öğrencilerinin Klinik Uygulamalarında Karşılaştıkları Sağlık Riskleri. DEUHEFED, 12(2), 116-125.

Chan, C. K. L., So, W. K. W. ve Fong, D. Y. T. (2009). Hong Kong Baccalaureate Nursing Students' Stress and Their Coping Strategies in Clinical Practice. Journal of Professional Nursing, 25(5), 307-313.

Chen, Y. W. ve Hung, C. H. (2014). Predictors of taiwanese baccalaureate nursing students' physiopsycho-social responses during clinical practicum. Nurse Education Today, 34(1), 73-77.

Chernomas, W. M. ve Shapiro, C. (2013). Stress, depression ve anxiety among undergraduate nursing students. International Journal of Nursing Education Scholarship, 10(1), 255-266.

Edwards, D., Burnard, P., Bennett, K. ve Hebden, U. (2010). A longitudinal study of stress and selfesteem in student nurses. Nurse Education Today, 30(1), 78-84.

Ergin, E., Çevik, K. ve Pakiş Çetin, S. (2018). Hemşirelik Öğrencilerinin Eğitimlerine İlişkin Algıladığı Stres ve Stresle Baş Etme Davranışlarının İncelenmesi. Hemşirelikte Eğitim ve Araştırma Dergisi, 15(1), 16-22.

Friborg, O., Barlaug, D., Martinussen, M., Rosenvinge Jan, H. ve Hjemdal, O. (2005). Resilience in relation to personality and intelligence. International Journal of Methods in Psychiatric Research, 14(1), 29-42.

Friborg, O., Hjemdal, O., Rosenvinge, J. H. ve Martinussen, M. (2003). A new rating scale for adult resilience: What are the central protective resources behind healthy adjustment? International Journal of Methods in Psychiatric Research, 12(2), 65-76.

Garmezy, N. (1991). Resiliency and Vulnerability to Adverse Developmental Outcomes Associated With Poverty. American Behavioral Scientist, 34(4), 416-430. 
Tarsuslu, B., Günaydın, N., \& Koc, M. (2020). Öğrenci hemșirelerde eğitim stresi ile psikolojik dayanıklılı arasındaki ilişki. Journal of Human Sciences, 17(1), 79-91. doi:10.14687/jhs.v17i1.5796

Gibbons, C. (2010). Stress, coping and burn-out in nursing students. International Journal of Nursing Studies, 47(10), 1299-1309.

Gibbons, C., Dempster, M. ve Moutray, M. (2011). Stress, coping and satisfaction in nursing students. Journal of Advanced Nursing, 67(3), 621-632.

Gillespie, B. M., Chaboyer, W. ve Wallis, M. (2009). The influence of personal characteristics on the resilience of operating room nurses: A predictor study. International Journal of Nursing Studies, 46(7), 968-976.

Goff, A. M. (2009). Stressors, academic performance, and learned resourcefulness in baccalaureate nursing students. Unpublished Thesis of the Degree Doctor of Philosophy. The University of North Carolina. 135 pp.

Grant, L. ve Kinman, G. (2014). Emotional Resilience in the Helping Professions and how it can be Enhanced. Health and Social Care Education, 3(1), 23-34.

Güngörmüş, K., Okanlı, A. ve Kocabeyoğlu, T. (2015). Hemşirelik Öğrencilerinin Psikolojik Dayanıklılıkları ve Etkileyen Faktörler. Journal of Psychiatric Nursing, 6(1), 9-14.

Haase, J. E. (2004). The adolescent resilience model as a guide to interventions. Journal of Pediatric Oncology Nursing, 21(5), 289-299.

Hart, P. L., Brannan, J. D. ve de Chesnay, M. (2014). Resilience in nurses: An integrative review. Journal of Nursing Management, 22(6), 720-734.

Jimenez, C., Navia-Osorio, P. M. ve Diaz, C. V. (2010). Stress and health in novice and experienced nursing students. Journal of Advanced Nursing, 66(2), 442-455.

Kang, Y. S., Choi, S. Y. ve Ryu, E. (2009). The effectiveness of a stress coping program based on mindfulness meditation on the stress, anxiety, and depression experienced by nursing students in Korea. Nurse Education Today, 29(5), 538-543.

Karaca, A., Yildirim, N., Ankarali, H. ve Açikgöz, F. (2014). Hemşirelik Eğitimi Stres Ölçeği ' nin Türkçeye Uyarlama1s. Hemşirelikte Araştırma Geliştirme Dergisi, 16(2), 29-40.

Karaca, A., Yildirim, N., Ankarali, H., Açikgöz, F. ve Akkuş, D. (2017). Hemşirelik Öğrencilerinin Algılanan Klinik Stres Düzeyi, Stres Cevapları ve Başetme Davranışları. Journal of Psychiatric Nursing, 8(1), 32-39.

Karairmak, Ö. ve Çetinkaya Siviş, R. (2011). Benlik Saygısının ve Denetim Odağının Psikolojik Sağlamlık Üzerine Etkisi: Duyguların Aracı Rolü. Türk Psikolojik Danışma ve Rehberlik Dergisi, 4(35), 30-43.

Karreman, A. ve Vingerhoets, A. J. J. M. (2012). Attachment and well-being: The mediating role of emotion regulation and resilience. Personality and Individual Differences, 53(7), 821-826.

Klainin-Yobas, P., Keawkerd, O., Pumpuang, W., Thunyadee, C., Thanoi, W. ve He, H. G. (2014). The mediating effects of coping on the stress and health relationships among nursing students: A structural equation modelling approach. Journal of Advanced Nursing, 70(6), 1287-1298.

Lee, M.-H., Holzemer, W. L. ve Faucett, J. (2007). Psychometric Evaluation of the Nursing Stress Scale (NSS) Among Chinese Nurses in Taiwan. Journal of Nursing Measurement, 15(2), 133-144.

Maville, J. A., Kranz, P. L. ve Tucker, B. A. (2004). Perceived stress reported by nurse practitioner students. Journal of the American Academy of Nurse Practitioners, 16(6), 257-262.

McCann, C. M., Beddoe, E., McCormick, K., Huggard, P., Kedge, S., Adamson, C. ve Huggard, J. (2013). Resilience in the health professions: A review of recent literature. International Journal of Wellbeing, 3(1), 60-81.

McDonald, G., Jackson, D., Wilkes, L. ve Vickers, M. H. (2012). A work-based educational intervention to support the development of personal resilience in nurses and midwives. Nurse Education Today, 32(4), 378-384.

Mealer, M., Jones, J., Newman, J., McFann, K. K., Rothbaum, B. ve Moss, M. (2012). The presence of resilience is associated with a healthier psychological profile in intensive care unit (ICU) nurses: Results of a national survey. International Journal of Nursing Studies, 49(3), 292-299.

Mooney, M. (2007). Professional socialization: The key to survival as a newly qualified nurse. International Journal of Nursing Practice, 13(2), 75-80.

Öner Altiok, H. ve Üstün, B. (2013). The stress sources of nursing students. Kuram ve Uygulamada Egitim Bilimleri, 13(2), 760-766. 
Tarsuslu, B., Günaydın, N., \& Koc, M. (2020). Öğrenci hemșirelerde eğitim stresi ile psikolojik dayanıklılı arasındaki ilişki. Journal of Human Sciences, 17(1), 79-91. doi:10.14687/jhs.v17i1.5796

Öz, F. ve Hiçdurmaz, D. (2010). Stresle Başetmede Önemli Bir Yol: Mizahın Kullanımı. Journal of Anatolia Nursing and Health Sciences, 13(1), 83-88.

Öz, F. ve Yılmaz, E. B. (2009). Ruh Sağlığının Korunmasında Önemli Bir Kavram: Psikolojik Sağlamlık. Hacettepe Üniversitesi Hemşirelik Fakültesi Dergisi, 16(3), 82-89.

Özer, K. A. (1994). Sürekli Öfke (SL-Öfke) ve Öfke İfade Tarzı (Öfke-Tarz) Ölçekleri Ön Çalışması. Türk Psikoloji Dergisi, 9(31), 26-35.

Ozsaban, A., Turan, N. ve Kaya, H. (2019). Resilience in Nursing Students: The Effect of Academic Stress and Social Support. Clinical and Experimental Health Sciences, 9, 69-76.

Pulido-Martos, M., Augusto-Landa, J. M. ve Lopez-Zafra, E. (2012). Sources of stress in nursing students: A systematic review of quantitative studies. International Nursing Review, Vol. 59, pp. $15-25$.

Schabracq, M. J., Winnubst, J. A. M. ve Cooper, C. L. (2004). The Handbook of Work and Health Psychology: Second Edition. In The Handbook of Work and Health Psychology: Second Edition.

Sheu, S., Lin, H. S. ve Hwang, S. L. (2002). Perceived stress and physio-psycho-social status of nursing students during their initial period of clinical practice: The effect of coping behaviors. International Journal of Nursing Studies, 39(2), 165-175.

Smith, G. D. ve Yang, F. (2017). Stress, resilience and psychological well-being in Chinese undergraduate nursing students. Nurse Education Today, 49(49), 90-95.

Sü, S., Özlük, B. ve Demirören, N. (2018). Hemşirelik öğrencilerinin ilk klinik uygulamada deneyimledikleri stres düzeylerini azaltmada mentorlük uygulamasının etkisi. Journal of Human Sciences, 15(1), 280.

Terzi, Ş. (2008). Üniversite öğrencilerinde kendini toparlama gücünün içsel koruyucu faktörlerle ilişkisi. Hacettepe Üniversitesi Eğitim Fakültesi Dergisi, (35), 297-306.

Tugade, M. M., Fredrickson, B. L. ve Barrett, L. F. (2004). Psychological resilience and positive emotional granularity: examining the benefits of positive emotions on coping and health. Journal of Personality, 72(6), 1161-1190.

Turner, K. ve McCarthy, V. L. (2017). Stress and anxiety among nursing students: A review of intervention strategies in literature between 2009 and 2015. Nurse Education in Practice, 22(22), 21-29.

Tusaie, K. ve Dyer, J. (2004). Resilience: A Historical Review of the Construct. Holistic Nursing Practice, January/Fe, 3-10.

Wagnild, G. M. ve Young, H. M. (1993). Development and psychometric evaluation of the resilience scale. Journal of Nursing Measurement1, 1(2), 165-178.

Wolf, L., Warner Stidham, A., Ross, R. ve Warner, A. (2015). Predictors of Stress and Coping Strategies of US Accelerated vs. Generic Baccalaureate Nursing Students: An Embedded Mixed Methods Study. Nursing Faculty Publications, 41, 201-205.

Yılmaz, M., Yaman, Z. ve Erdoğan, S. (2017). Öğrenci hemşirelerde stres yaratan durumlar ve baş etme yöntemleri. Mersin Üniversitesi Sağlık Bilimleri Dergisi, 10(2).

\section{Extended English Summary}

Knowing that understanding and revealing the relationship between stress sources and psychological Resilience levels of nursing students is important for students to gain a professional occupational identity. During their education, it is important that the nurses who work with both social problems and healthy/sick individuals, families and society who are in crisis have strong support in every way and graduate. It is important to reveal the relationship between academic and theoretical educational stress and psychological resilience of nursing students in order to graduate by gaining professional change, development and professional knowledge, attitude and skills. In this respect, this study was conducted to determine the relationship between educational stress and psychological Resilience of nursing students and the factors affecting them. 
Tarsuslu, B., Günaydın, N., \& Koc, M. (2020). Öğrenci hemșirelerde eğitim stresi ile psikolojik dayanıklılı arasındaki ilişki. Journal of Human Sciences, 17(1), 79-91. doi:10.14687/jhs.v17i1.5796

The current study population consisted of 602 nursing students attending the Faculty of Health Sciences of Ordu University and Gaziosmanpaşa University of Tokat, Turkey; this study was conducted between March and April, 2018. The data collected with Nursing Education Stress Scale (NESS), and Resilience Scale for Adults (RSA). Nursing Education Stress Scale (NESS) was used to evaluate the stress experienced by nursing students during their education. NESS consists of 32 items and two subdimensions (application stress and academic stress). The adaptation of the measurement tool to Turkish was performed by Karaca ve ark. (2014). Resilience Scale for Adults (RSA). RSA was developed by Friborg ve ark. (2003) includes sub-dimensions of 'personal strength', 'structural style', 'social competence', 'family cohesion' and 'social resources'. The validity-reliability study of the Turkish version of the RSA was performed by Basim and Cetin (2011). The increase in the scores obtained from the scale shows that the psychological Resilience levels of the participants are high. Data, frequency distribution, descriptive statistics (mean, standard deviation) Mann Whitney U test, Kruskal Wallis test, and Spearman correlation test were used.

Mean age of the study group students is $20.37 \pm 2.10$ (min: 17, max: 36 ), $73.8 \%$ were female and $26.2 \%$ were male. $32.6 \%$ of students participating in the study were in their first year, while $26.9 \%$ were in their second, $24.1 \%$ were in their third and $16.4 \%$ were in their fourth year. $67.6 \%$ of students were staying at the university dormitory while $13.8 \%$ were staying at a house and $18.6 \%$ were living with their families. In addition, $27.7 \%$ of students had an emotional relationship, $8.5 \%$ had a chronic disease and $4.5 \%$ had a mental disorder.

The mean NESS score was $66.76 \pm 16.56$, and the mean RSA score was 99.99 \pm 5.19 . The median scores of the structural style, future perception and self-perception scores of the female students were higher than the male students. It was seen that the students who had emotional relationship had higher structural style and future perception of median score than those who did not. First year students had lower structural style of median score than 4th year students. On the other hand, according to the chronic physical and mental illness status of the students, it was found that the median scores of NESS and RSA did not differ (Table 2).

While there was no statistically significant relationship between the ages of the students and NESS scores, there was a moderate positive correlation between the age and social resources subdimension of RSA. The results of the correlation between NESS and mean RSA scores are given in Table 4. A significant positive correlation was found between NESS total, academic, application stress sub-dimensions and structural style, future perception of RSA. It was found that there was a negative correlation between NESS total, academic stress sub-dimension and social resources. Also, a statistically negative relationship was found between academic stress and family cohesion.

The stress level of the individual is affected by factors such as gender, age and economic status. In the study by Ergin ve ark. (2018) examining the perceived stress and coping styles of nursing students, no significant difference was found between academic stress levels by gender. On the other hand, the researchers found that the application stress score was higher in female students (Ergin ve ark., 2018). In our study, in addition to the results of the study of Çakar ve ark. (2019), the total, academic and application stress levels of female students were significantly higher than boys.

Karaca ve ark. (2017) found that Turkish students experienced higher levels of stress than students in other countries. In the literature, it is reported that students experience stress due to teaching staff and nurses and experience stress due to interaction with patients (Ergin ve ark., 2018; Öner Altiok \& Üstün, 2013). The presence of social support has positive effects on psychological well-being and affects mental health positively by reducing stress level (Armstrong ve ark., 2011; Karreman \& Vingerhoets, 2012).

As a result, nursing students experience moderate academic and practice stress. Female students experience more stress than male students and staying in dormitories than students staying at home. In addition, female students are psychologically stronger in the areas of structural style, future perception, and self-perception, which are the sub-factors of psychological resilience. Among the factors that affect students' psychological well-being, there is a positive relationship between personal characteristics and future goals, quests and adaptation to future, and stress (in practice area). In addition, it can be said that the psychological resilience of the students is moderate when the scores of the students are evaluated. 
Tarsuslu, B., Günaydın, N., \& Koc, M. (2020). Öğrenci hemşirelerde eğitim stresi ile psikolojik dayanıklılık arasındaki ilişki. Journal of Human Sciences, 17(1), 79-91. doi:10.14687/jhs.v17i1.5796

\section{TABLOLAR}

Tablo 1: Sosyo-demografik özellikler

\begin{tabular}{|c|c|c|c|c|c|}
\hline Değişken & & Min & Max & Ort & SS \\
\hline \multirow[t]{2}{*}{ Yaş } & & 17,00 & 36,00 & 20,37 & 2,10 \\
\hline & & $\mathbf{n}$ & $\%$ & & \\
\hline \multirow[t]{2}{*}{ Üniversite } & Gaziosmanpaşa Üniversitesi & 370 & 61,5 & & \\
\hline & Ordu Üniversitesi & 232 & 38,5 & & \\
\hline \multirow[t]{2}{*}{ Cinsiyet } & Kadin & 444 & 73,8 & & \\
\hline & Erkek & 158 & 26,2 & & \\
\hline \multirow[t]{4}{*}{ Sinif } & 1.Sinif & 196 & 32,6 & & \\
\hline & 2.Sinif & 162 & 26,9 & & \\
\hline & 3.Sinif & 145 & 24,1 & & \\
\hline & 4.Sinif & 99 & 16,4 & & \\
\hline \multirow[t]{3}{*}{ Kalınan Yer } & Yurt & 407 & 67,6 & & \\
\hline & Aile Yanı & 112 & 18,6 & & \\
\hline & $\mathrm{Ev}$ & 83 & 13,8 & & \\
\hline Ekonomik & Düşük & 35 & 5,8 & & \\
\hline \multirow[t]{2}{*}{ Durum } & Orta & 417 & 69,3 & & \\
\hline & İyi & 150 & 24,9 & & \\
\hline \multirow[t]{2}{*}{ Romantik İlişki } & Var & 167 & 27,7 & & \\
\hline & Yok & 435 & 72,3 & & \\
\hline \multirow[t]{2}{*}{ Kronik Hastalık } & Var & 51 & 8,5 & & \\
\hline & Yok & 551 & 91,5 & & \\
\hline \multirow[t]{2}{*}{ Ruhsal Hastalık } & Var & 27 & 4,5 & & \\
\hline & Yok & 575 & 95,5 & & \\
\hline Toplam & & 602 & 100 & & \\
\hline
\end{tabular}

Tablo 2: Ölçeklere ait Cronbach alpha değeri ve tanımlayıcı istatistikler

\begin{tabular}{|c|c|c|c|c|c|c|c|}
\hline Ölçek & $\begin{array}{c}\text { Conbach } \\
\text { Alpha }\end{array}$ & Ort. & Sd & Medyan & IQR & Min & Max \\
\hline Uygulama stresi & 0,89 & 33,21 & 8,77 & 34,00 & 12,25 & 0,00 & 48,00 \\
\hline Akademik stres & 0,87 & $33,55 \pm$ & 8,65 & 34,00 & 12,00 & 0,00 & 48,00 \\
\hline HESÖ toplam & 0,93 & 66,76 & 16,56 & 68,00 & 23,00 & 0,00 & 96,00 \\
\hline Yapisal stil & 0,65 & 41,487 & 16,10 & 12,00 & 2,00 & 0,00 & 12,00 \\
\hline Gelecek alg1s1 & 0,60 & 12,267 & 2,45 & 12,00 & 2,00 & 0,00 & 12,00 \\
\hline Aile uyumu & 0,84 & 18,93 & 2,29 & 19,00 & 3,00 & 10,00 & 26,00 \\
\hline Kendilik alg1s1 & 0,73 & 18,54 & 2,04 & 18,00 & 3,00 & 9,00 & 25,00 \\
\hline Sosyal yeterlilik & 0,75 & 18,32 & 1,99 & 18,00 & 2,25 & 11,00 & 25,00 \\
\hline Sosyal kaynaklar & 0,79 & 19,78 & 2,39 & 20,00 & 3,00 & 12,00 & 28,00 \\
\hline YPDÖ toplam & 0,93 & 99,99 & 5,19 & 100,00 & 6,00 & 79,00 & 139,00 \\
\hline
\end{tabular}

Tablo 4: Ölçek puanları ile yaş arasındaki ilişki

\begin{tabular}{|c|c|c|c|c|c|c|c|c|c|c|c|}
\hline & & Uygulama & Akademik & $\begin{array}{l}\text { HESÖ } \\
\text { Toplam }\end{array}$ & $\begin{array}{c}\text { Yapisal } \\
\text { Stil }\end{array}$ & $\begin{array}{c}\text { Gelecek } \\
\text { Algis1 }\end{array}$ & $\begin{array}{c}\text { Aile } \\
\text { Uyumu }\end{array}$ & $\begin{array}{c}\text { Kendilik } \\
\text { Alg1s1 }\end{array}$ & $\begin{array}{c}\text { Sosyal } \\
\text { Yeterlilik }\end{array}$ & $\begin{array}{c}\text { Sosyal } \\
\text { Kaynaklar }\end{array}$ & $\begin{array}{l}\text { YPDÖ } \\
\text { Toplam }\end{array}$ \\
\hline \multirow{2}{*}{ Yaş } & $\mathrm{r}$ & $-0,004$ & 0,024 & 0,014 & 0,060 & 0,010 & 0,017 & $-0,065$ & 0,022 & $-0,041$ & $-0,020$ \\
\hline & $\mathrm{p}$ & 0,927 & 0,557 & 0,728 & 0,144 & 0,798 & 0,669 & 0,110 & 0,592 & 0,319 & 0,631 \\
\hline
\end{tabular}

r: spearman korelasyon analizi

Tablo 5: Ölçeklerin birbiri ile ilişkisi

\begin{tabular}{ccccccccc}
\hline & & Yapisal Stil & $\begin{array}{c}\text { Gelecek } \\
\text { Algisi }\end{array}$ & Aile Uyumu & $\begin{array}{c}\text { Kendilik } \\
\text { Alg1si }\end{array}$ & $\begin{array}{c}\text { Sosyal } \\
\text { Yeterlilik }\end{array}$ & $\begin{array}{c}\text { Sosyal } \\
\text { Kaynaklar }\end{array}$ & $\begin{array}{c}\text { YPDÖ } \\
\text { toplam }\end{array}$ \\
\hline \multirow{2}{*}{ Uygulama } & $\mathrm{r}$ & $\mathbf{0 , 8 1 5 *}$ & $\mathbf{0 , 6 9 9 *}$ & $-0,047$ & 0,034 & 0,029 & $-0,076$ \\
& $\mathrm{p}$ & $\mathbf{0 , 0 0 0}$ & $\mathbf{0 , 0 0 0}$ & 0,251 & 0,411 & 0,476 & 0,063 & 0,658 \\
\hline \multirow{2}{*}{ Akademik } & $\mathrm{r}$ & $\mathbf{0 , 7 4 5 *}$ & $\mathbf{0 , 8 4 0 *}$ & $\mathbf{- 0 , 1 0 1 *}$ & 0,061 & 0,075 & $-\mathbf{0 , 1 0 0 *}$ & $-0,029$ \\
& $\mathrm{p}$ & $\mathbf{0 , 0 0 0}$ & $\mathbf{0 , 0 0 0}$ & $\mathbf{0 , 0 1 3}$ & 0,137 & 0,064 & $\mathbf{0 , 0 1 4}$ & 0,471 \\
\hline \multirow{2}{*}{ HESÖ toplam } & $\mathrm{r}$ & $\mathbf{0 , 8 2 5 *}$ & $\mathbf{0 , 8 1 4 *}$ & $-0,071$ & 0,051 & 0,059 & $\mathbf{- 0 , 0 9 2 *}$ & $-0,020$ \\
& $\mathrm{p}$ & $\mathbf{0 , 0 0 0}$ & $\mathbf{0 , 0 0 0}$ & 0,082 & 0,211 & 0,149 & $\mathbf{0 , 0 2 5}$ & 0,625 \\
\hline r: spearman korelasyon analizi & & & & & &
\end{tabular}

r: spearman korelasyon analizi 
90

Tarsuslu, B., Günaydın, N., \& Koc, M. (2020). Öğrenci hemşirelerde eğitim stresi ile psikolojik dayanıklılık arasındaki ilişki. Journal of Human Sciences, 17(1), 79-91. doi:10.14687/jhs.v17i1.5796

Tablo 3: Sosyodemografik özelliklere göre Hemşirelik Eğitim Stresi Ölçeği ve Yetişkinler İçin Psikolojik Dayanıklılık Ölçeği puan ortancalarının (medyan) dağılımı

\begin{tabular}{|c|c|c|c|c|c|c|c|c|c|c|c|c|c|c|c|c|c|c|c|c|c|}
\hline \multicolumn{2}{|c|}{$\begin{array}{l}\text { Sosyodemografi } \\
\text { k Veriler }\end{array}$} & \multicolumn{2}{|c|}{ HESÖ Toplam } & \multicolumn{2}{|c|}{ Uygulama } & \multicolumn{2}{|c|}{ Akademik } & \multicolumn{2}{|c|}{ YPDÖ Toplam } & \multicolumn{2}{|c|}{ Yapısal Stil } & \multicolumn{2}{|c|}{ Gelecek Alg1s1 } & \multicolumn{2}{|c|}{ Aile Uyumu } & \multicolumn{2}{|c|}{ Kendilik Algısı } & \multicolumn{2}{|c|}{$\begin{array}{c}\text { Sosyal } \\
\text { Yeterlilik }\end{array}$} & \multicolumn{2}{|c|}{$\begin{array}{c}\text { Sosyal } \\
\text { Kaynaklar }\end{array}$} \\
\hline & $\mathrm{n}$ & $\begin{array}{l}\text { Medy } \\
\text { an } \\
\text { (IQR) }\end{array}$ & $\begin{array}{l}\mathrm{Z} / \mathrm{K} \\
\mathrm{W} ; \mathrm{p}\end{array}$ & $\begin{array}{c}\text { Medy } \\
\text { an } \\
\text { (IQR) }\end{array}$ & $\begin{array}{l}\mathrm{Z} / \mathrm{K} \\
\mathrm{W} ; \mathrm{p}\end{array}$ & $\begin{array}{c}\text { Medy } \\
\text { an } \\
\text { (IQR) }\end{array}$ & $\begin{array}{l}\mathrm{Z} / \mathrm{KW} \\
\mathrm{p}\end{array}$ & $\begin{array}{c}\text { Medya } \\
\text { n } \\
\text { (IQR) }\end{array}$ & $\begin{array}{l}\mathrm{Z} / \mathrm{KW} \\
\mathrm{p}\end{array}$ & $\begin{array}{c}\text { Medyan } \\
\text { (IQR) }\end{array}$ & $\begin{array}{c}\mathrm{Z} / \mathrm{KW} \\
; \mathrm{p}\end{array}$ & $\begin{array}{c}\text { Medya } \\
\text { n } \\
\text { (IQR) }\end{array}$ & $\begin{array}{l}\mathrm{Z} / \mathrm{K} \\
\mathrm{W} ; \mathrm{p}\end{array}$ & $\begin{array}{c}\text { Med } \\
\text { yan } \\
\text { (IQR } \\
\text { ) }\end{array}$ & $\begin{array}{l}\mathrm{Z} / \mathrm{KW} \\
\mathrm{p}\end{array}$ & $\begin{array}{l}\text { Medy } \\
\text { an } \\
\text { (IQR) }\end{array}$ & $\begin{array}{l}\mathrm{Z} / \mathrm{K} \\
\mathrm{W} ; \mathrm{p}\end{array}$ & $\begin{array}{l}\text { Medy } \\
\text { an } \\
\text { (IQR) }\end{array}$ & $\begin{array}{l}\mathrm{Z} / \mathrm{K} \\
\mathrm{W} ; \mathrm{p}\end{array}$ & $\begin{array}{c}\text { Medy } \\
\text { an } \\
\text { (IQR) }\end{array}$ & $\begin{array}{l}\mathrm{Z} / \mathrm{K} \\
\mathrm{W} ; \mathrm{p}\end{array}$ \\
\hline \multicolumn{22}{|l|}{ Cinsiyet } \\
\hline Kadın & 158 & $\begin{array}{c}70,00 \\
(20,00) \\
\\
59,50 \\
(25,25)\end{array}$ & $\begin{array}{l}-5,957 \\
0,000^{*}\end{array}$ & $\begin{array}{c}35,00 \\
(10,00) \\
\\
29,00 \\
(14,25)\end{array}$ & $\begin{array}{l}-5,951 \\
0,000^{*}\end{array}$ & $\begin{array}{c}36,00 \\
(11,00)\end{array}$ & $\begin{array}{l}-5,300 \\
0,000 *\end{array}$ & $\begin{array}{l}100,00 \\
(6,00) \\
\\
99,50 \\
(5,00)\end{array}$ & $\begin{array}{c}-1,413 \\
0,158\end{array}$ & $\begin{array}{c}8,00 \\
(3,00) \\
\\
7,00 \\
(4,00)\end{array}$ & $\begin{array}{l}-4,252 \\
0,000^{*}\end{array}$ & $\begin{array}{c}9,00 \\
(3,00) \\
\\
7,00 \\
(4,00)\end{array}$ & $\begin{array}{c}-5,143 \\
0,000 \\
*\end{array}$ & $\begin{array}{l}19,00 \\
(3,00) \\
\\
19,00 \\
(3,00)\end{array}$ & $\begin{array}{c}-0,119 \\
0,905\end{array}$ & $\begin{array}{l}19,00 \\
(3,00) \\
\\
18,00 \\
(2,00)\end{array}$ & $\begin{array}{l}-2,353 \\
0,019 *\end{array}$ & $\begin{array}{l}18,00 \\
(2,00) \\
\\
18,00 \\
(3,00)\end{array}$ & $\begin{array}{l}-0,106 \\
0,915\end{array}$ & $\begin{array}{l}20,00 \\
(3,00) \\
\\
20,00 \\
(3,00)\end{array}$ & $\begin{array}{r}-0,935 \\
0,350\end{array}$ \\
\hline \multicolumn{22}{|c|}{ Romantik İlişki } \\
\hline Yok & 435 & $\begin{array}{c}69,00 \\
(25,00) \\
\\
68,00 \\
(23,00)\end{array}$ & $\begin{array}{r}-1,151 \\
0,250\end{array}$ & $\begin{array}{c}33,00 \\
(13,00) \\
\\
34,00 \\
(11,00)\end{array}$ & $\begin{array}{c}-0,359 \\
0,720\end{array}$ & $\begin{array}{c}34,00 \\
(12,00)\end{array}$ & $\begin{array}{l}-1,755 \\
0,079\end{array}$ & $\begin{array}{c}100,00 \\
(6,00) \\
100,00 \\
(6,00)\end{array}$ & $\begin{array}{c}-0,317 \\
0,751\end{array}$ & $\begin{array}{c}9,00 \\
(3,00) \\
\\
8,00 \\
(3,00)\end{array}$ & $\begin{array}{c}-1,948 \\
0,051\end{array}$ & $\begin{array}{c}9,00 \\
(3,00) \\
\\
8,00 \\
(4,00)\end{array}$ & $\begin{array}{c}-2,150 \\
0,032 \\
*\end{array}$ & $\begin{array}{l}19,00 \\
(3,00) \\
\\
19,00 \\
(3,00)\end{array}$ & $\begin{array}{c}-1,460 \\
0,144\end{array}$ & $\begin{array}{l}18,00 \\
(2,00) \\
\\
18,00 \\
(3,00)\end{array}$ & $\begin{array}{c}-0,522 \\
0,601\end{array}$ & $\begin{array}{l}18,00 \\
(3,00) \\
\\
18,00 \\
(2,00)\end{array}$ & $\begin{array}{c}-0,568 \\
0,570\end{array}$ & $\begin{array}{l}20,00 \\
(3,00) \\
\\
20,00 \\
(3,00)\end{array}$ & $\begin{array}{r}-0,757 \\
0,449\end{array}$ \\
\hline Sinif & & & & & & & & & & & & & & & & & & & & & \\
\hline 1.sinif & 196 & $\begin{array}{c}67,00 \\
(22,00)\end{array}$ & & $\begin{array}{c}34,00 \\
(12,00)\end{array}$ & & $\begin{array}{c}33,00 \\
(11,00)\end{array}$ & & $\begin{array}{l}100,00 \\
(6,00)\end{array}$ & & $\begin{array}{l}8,00 \\
(4,00)\end{array}$ & & $\begin{array}{c}8,00 \\
(4,00)\end{array}$ & & $\begin{array}{l}19,00 \\
(3,00)\end{array}$ & & $\begin{array}{l}18,00 \\
(3,00)\end{array}$ & & $\begin{array}{l}18,00 \\
(3,00)\end{array}$ & & $\begin{array}{l}20,00 \\
(3,00)\end{array}$ & \\
\hline 2. sinif & 162 & $\begin{array}{c}70,00 \\
(24,00)\end{array}$ & 4,164 & $\begin{array}{c}34,00 \\
(11,25)\end{array}$ & 1,295 & $\begin{array}{c}36,00 \\
(12,00)\end{array}$ & 7,893 & $\begin{array}{l}100,00 \\
(6,00)\end{array}$ & 3,006 & $\begin{array}{c}8,00 \\
(3,00)\end{array}$ & $\begin{array}{l}10,363 \\
0,016^{*}\end{array}$ & $\begin{array}{c}9,00 \\
(4,00)\end{array}$ & 3,917 & $\begin{array}{l}19,00 \\
(3,00)\end{array}$ & 0,928 & $\begin{array}{l}19,00 \\
(2,00)\end{array}$ & 3,902 & $\begin{array}{l}18,00 \\
(3,00)\end{array}$ & 0,666 & $\begin{array}{l}20,00 \\
(2,25)\end{array}$ & 4,618 \\
\hline 3. sinif & 145 & $\begin{array}{c}68,00 \\
(23,50)\end{array}$ & 0,244 & $\begin{array}{c}33,00 \\
(13,00)\end{array}$ & 0,730 & $\begin{array}{c}35,00 \\
(13,00)\end{array}$ & $0,048^{*}$ & $\begin{array}{l}100,00 \\
(6,00)\end{array}$ & 0,391 & $\begin{array}{c}8,00 \\
(3,00)\end{array}$ & $1<4$ & $\begin{array}{c}9,00 \\
(3,00)\end{array}$ & 0,271 & $\begin{array}{l}19,00 \\
(3,00)\end{array}$ & 0,819 & $\begin{array}{c}19,0 \\
(3,00)\end{array}$ & 0,272 & $\begin{array}{l}18,00 \\
(2,00)\end{array}$ & 0,881 & $\begin{array}{l}20,00 \\
(3,50)\end{array}$ & 0,202 \\
\hline 4. sinif & 99 & $\begin{array}{l}71,00 \\
(23,00)\end{array}$ & & $\begin{array}{c}36,00 \\
(13,00)\end{array}$ & & $\begin{array}{c}35,00 \\
(13,00)\end{array}$ & & $\begin{array}{l}99,00 \\
(5,00)\end{array}$ & & $\begin{array}{c}9,00 \\
(4,00)\end{array}$ & & $\begin{array}{c}9,00 \\
(3,00)\end{array}$ & & $\begin{array}{l}19,00 \\
(3,00)\end{array}$ & & $\begin{array}{l}18,00 \\
(2,00)\end{array}$ & & $\begin{array}{l}18,00 \\
(2,00)\end{array}$ & & $\begin{array}{c}19,0 \\
(3,00)\end{array}$ & \\
\hline Kalınan & & & & & & & & & & & & & & & & & & & & & \\
\hline Yurt & 407 & $\begin{array}{c}70,00 \\
(24,00)\end{array}$ & $\begin{array}{c}6,094 \\
0,047 *\end{array}$ & $\begin{array}{c}35,00 \\
(12,00)\end{array}$ & $\begin{array}{l}4,259 \\
0,119\end{array}$ & $\begin{array}{c}36,00 \\
(12,00)\end{array}$ & $\begin{array}{c}6,921 \\
0,031 * \\
\text { Yurt }>\end{array}$ & $\begin{array}{l}100,00 \\
(6,00)\end{array}$ & $\begin{array}{l}0,139 \\
0,933\end{array}$ & $\begin{array}{c}8,00 \\
(3,00)\end{array}$ & $\begin{array}{l}1,306 \\
0,520\end{array}$ & $\begin{array}{c}9,00 \\
(3,00)\end{array}$ & $\begin{array}{l}4,100 \\
0,129\end{array}$ & $\begin{array}{l}19,00 \\
(3,00)\end{array}$ & $\begin{array}{l}3,596 \\
0,166\end{array}$ & $\begin{array}{l}18,00 \\
(3,00)\end{array}$ & $\begin{array}{l}0,986 \\
0,611\end{array}$ & $\begin{array}{l}18,00 \\
(2,00)\end{array}$ & $\begin{array}{l}0,358 \\
0,836\end{array}$ & $\begin{array}{l}20,00 \\
(3,00)\end{array}$ & $\begin{array}{l}0,536 \\
0,765\end{array}$ \\
\hline Aile & 112 & 66,50 & & 33,00 & & 33,5 & aile & 99,00 & & 8,00 & & 8,00 & & 19,00 & & 18,00 & & 18,00 & & 20,00 & \\
\hline
\end{tabular}


91

Tarsuslu, B., Günaydın, N., \& Koc, M. (2020). Öğrenci hemşirelerde eğitim stresi ile psikolojik dayanıklllık arasındaki ilişki. Journal of Human Sciences, 17(1), 79-91. doi:10.14687/ihs.v17i1.5796

\begin{tabular}{|c|c|c|c|c|c|c|c|c|c|c|c|c|c|c|c|c|c|c|c|c|c|}
\hline \multirow{2}{*}{\multicolumn{2}{|c|}{$\begin{array}{c}\begin{array}{c}\text { Sosyodemografi } \\
\text { k Veriler }\end{array} \\
\text { yanı }\end{array}$}} & \multirow{2}{*}{$\begin{array}{c}\text { HESÖ } \\
(19,00)\end{array}$} & \multirow{2}{*}{ Toplam } & \multicolumn{2}{|c|}{ Uygulama } & \multicolumn{2}{|c|}{ Akademik } & \multicolumn{2}{|c|}{ YPDÖ Toplam } & \multicolumn{2}{|c|}{ Yapisal Stil } & \multicolumn{2}{|c|}{ Gelecek Alg1s1 } & \multicolumn{2}{|c|}{ Aile Uyumu } & \multicolumn{2}{|c|}{ Kendilik Alg1sı } & \multicolumn{2}{|c|}{$\begin{array}{c}\text { Sosyal } \\
\text { Yeterlilik }\end{array}$} & \multicolumn{2}{|c|}{$\begin{array}{c}\text { Sosyal } \\
\text { Kaynaklar }\end{array}$} \\
\hline & & & & $(10,75)$ & & $(11,00)$ & yanı & $(6,00)$ & & $(3,75)$ & & $(3,00)$ & & $(3,00)$ & & $(3,00)$ & & $(2,75)$ & & $(3,00)$ & \\
\hline Ev & 83 & $\begin{array}{c}65,00 \\
(24,00)\end{array}$ & & $\begin{array}{c}33,00 \\
(12,00)\end{array}$ & & $\begin{array}{c}33,00 \\
(13,00)\end{array}$ & & $\begin{array}{c}100,00 \\
(6,00)\end{array}$ & & $\begin{array}{r}8,00 \\
(4,00)\end{array}$ & & $\begin{array}{c}8,00 \\
(4,00)\end{array}$ & & $\begin{array}{l}19,00 \\
(3,00)\end{array}$ & & $\begin{array}{l}18,00 \\
(3,00)\end{array}$ & & $\begin{array}{l}18,00 \\
(3,00)\end{array}$ & & $\begin{array}{l}20,00 \\
(3,00)\end{array}$ & \\
\hline \multicolumn{22}{|c|}{ Ekonomik durum } \\
\hline Düşük & 35 & $\begin{array}{c}68,00 \\
(19,00)\end{array}$ & & $\begin{array}{l}33,00 \\
(9,00)\end{array}$ & & $\begin{array}{c}34,00 \\
(13,00)\end{array}$ & & $\begin{array}{l}97,00 \\
(7,00)\end{array}$ & 10,302 & $\begin{array}{c}8,00 \\
(3,00)\end{array}$ & & $\begin{array}{c}9,00 \\
(3,00)\end{array}$ & & $\begin{array}{l}18,00 \\
(4,00)\end{array}$ & 16282 & $\begin{array}{l}18,00 \\
(3,00)\end{array}$ & & $\begin{array}{l}18,00 \\
(3,00)\end{array}$ & & $\begin{array}{l}20,00 \\
(4,00)\end{array}$ & \\
\hline Orta & 417 & $\begin{array}{c}70,00 \\
(24,00)\end{array}$ & $\begin{array}{c}8,017 \\
0,018^{*}\end{array}$ & $\begin{array}{c}35,00 \\
(12,00)\end{array}$ & $\begin{array}{l}5,708 \\
0,058\end{array}$ & $\begin{array}{c}35,00 \\
(13,00)\end{array}$ & $\begin{array}{c}8,218 \\
0,016^{*}\end{array}$ & $\begin{array}{l}100,00 \\
(6,00)\end{array}$ & $\begin{array}{l}0,006 \\
\text { Orta- } \\
\text { İyi> }\end{array}$ & $\begin{array}{c}8,00 \\
(3,00)\end{array}$ & $\begin{array}{l}0,552 \\
0,759\end{array}$ & $\begin{array}{c}9,00 \\
(3,00)\end{array}$ & $\begin{array}{l}3,322 \\
0,190\end{array}$ & $\begin{array}{l}19,00 \\
(2,00)\end{array}$ & $\begin{array}{c}10,282 \\
0,000^{*} \\
\text { İyi }> \\
\text { Düsük }\end{array}$ & $\begin{array}{l}18,00 \\
(3,00)\end{array}$ & $\begin{array}{l}1,216 \\
0,544\end{array}$ & $\begin{array}{l}18,00 \\
(3,00)\end{array}$ & $\begin{array}{l}1,210 \\
0,546\end{array}$ & $\begin{array}{l}20,00 \\
(3,00)\end{array}$ & $\begin{array}{l}0,297 \\
0,862\end{array}$ \\
\hline İyi & 150 & $\begin{array}{c}64,50 \\
(21,00)\end{array}$ & & $\begin{array}{c}33,00 \\
(11,00)\end{array}$ & & $\begin{array}{c}32,50 \\
(11,00)\end{array}$ & & $\begin{array}{c}100,00 \\
(6,00)\end{array}$ & Düşük & $\begin{array}{c}8,00 \\
(4,00)\end{array}$ & & $\begin{array}{c}8,00 \\
(4,00)\end{array}$ & & $\begin{array}{l}20,00 \\
(3,00)\end{array}$ & & $\begin{array}{l}19,00 \\
(3,00)\end{array}$ & & $\begin{array}{l}18,00 \\
(2,00)\end{array}$ & & $\begin{array}{l}20,00 \\
(3,00)\end{array}$ & \\
\hline \multicolumn{22}{|c|}{ Fiziksel hastalık } \\
\hline Var & 51 & $\begin{array}{c}66,00 \\
(24,00)\end{array}$ & $-0,161$ & $\begin{array}{c}33,00 \\
(12,00)\end{array}$ & $-0,211$ & $\begin{array}{c}33,00 \\
(15,00)\end{array}$ & $-0,412$ & $\begin{array}{c}101,00 \\
(9,00)\end{array}$ & $-1,376$ & $\begin{array}{c}8,00 \\
(5,00)\end{array}$ & $-0,293$ & $\begin{array}{c}8,00 \\
(4,00)\end{array}$ & $-1,150$ & $\begin{array}{l}19,00 \\
(3,00)\end{array}$ & $-0,527$ & $\begin{array}{l}19,00 \\
(2,00)\end{array}$ & $-0,487$ & $\begin{array}{l}19,00 \\
(2,00)\end{array}$ & $-1,757$ & $\begin{array}{l}19,00 \\
(4,00)\end{array}$ & $-0,981$ \\
\hline Yok & 551 & $\begin{array}{c}69,00 \\
(23,00)\end{array}$ & 0,872 & $\begin{array}{c}34,00 \\
(13,00)\end{array}$ & 0,833 & $\begin{array}{c}34,00 \\
(12,00)\end{array}$ & 0,680 & $\begin{array}{c}100,00 \\
(6,00)\end{array}$ & 0,169 & $\begin{array}{c}8,00 \\
(3,00)\end{array}$ & 0,770 & $\begin{array}{c}9,00 \\
(3,00)\end{array}$ & 0,250 & $\begin{array}{l}19,00 \\
(3,00)\end{array}$ & 0,598 & $\begin{array}{l}18,00 \\
(3,00)\end{array}$ & 0,626 & $\begin{array}{l}18,00 \\
(2,00)\end{array}$ & 0,079 & $\begin{array}{l}20,00 \\
(3,00)\end{array}$ & \\
\hline \multicolumn{22}{|c|}{ Ruhsal hastalık } \\
\hline Var & 27 & $\begin{array}{c}69,00 \\
(30,00)\end{array}$ & $-0,686$ & $\begin{array}{c}34,00 \\
(13,00)\end{array}$ & $-0,228$ & $\begin{array}{c}34,00 \\
(14,00)\end{array}$ & $-1,124$ & $\begin{array}{c}100,00 \\
(9,00)\end{array}$ & $-0,725$ & $\begin{array}{c}9,00 \\
(4,00)\end{array}$ & $-1,273$ & $\begin{array}{c}9,00 \\
(4,00)\end{array}$ & $-0,922$ & $\begin{array}{l}19,00 \\
(3,00)\end{array}$ & $-1,417$ & $\begin{array}{l}18,00 \\
(2,00)\end{array}$ & $-0,571$ & $\begin{array}{l}19,00 \\
(2,00)\end{array}$ & $-1,728$ & $\begin{array}{l}20,00 \\
(3,00)\end{array}$ & $-0,288$ \\
\hline Yok & 575 & $\begin{array}{c}68,00 \\
(23,00)\end{array}$ & 0,493 & $\begin{array}{c}34,00 \\
(11,00)\end{array}$ & 0,820 & $\begin{array}{c}34,00 \\
(12,00)\end{array}$ & 0,261 & $\begin{array}{c}100,00 \\
(6,00)\end{array}$ & 0,469 & $\begin{array}{c}8,00 \\
(3,00)\end{array}$ & 0,203 & $\begin{array}{c}9,00 \\
(3,00)\end{array}$ & 0,356 & $\begin{array}{l}19,00 \\
(3,00)\end{array}$ & 0,157 & $\begin{array}{l}18,00 \\
(3,00)\end{array}$ & 0,568 & $\begin{array}{l}18,00 \\
(2,00)\end{array}$ & 0,084 & $\begin{array}{l}20,00 \\
(3,00)\end{array}$ & 0,773 \\
\hline
\end{tabular}

